\title{
Application of Photovoltaic Cells as a Power Supply for Smart Greenhouse Project
}

\author{
Syifaul Fuada ${ }^{\mathrm{a} *}$, Pribadi $^{\mathrm{b}}$, Mohammad Thobib $^{\mathrm{c}}$, Nur Jannah $^{\mathrm{b}}$, Risfanda A. ${ }^{\mathrm{b}}$ \\ ${ }^{a}$ Electrical Engineering Departement, State University of Malang (UM), Malang 65145, East Java, Indonesia \\ ${ }^{b}$ Civil Engineering Departement, State University of Malang (UM), Malang 65145, East Java, Indonesia \\ ${ }^{c}$ Social Science Departement, State University of Malang (UM), Malang 65145, East Java, Indonesia
}

\begin{abstract}
Glass house farming system has many advantages, for example the easiness to control pests and diseases, improves the production and quality of the products. On the other hand, this system needs additional energy so that it needs more production cost. To suppress the energy use, photovoltaic is needed maximally to be applied as a power supply for greenhouse. In this paper, the authors design a smart greenhouse that takes care of plants, which is automatic watering, automatically open and close canopy, automatic temperature control. This project is named as smart greenhouse, the placing of this smart greenhouse is on the rooftop of a house.
\end{abstract}

Keywords: Green roof ; greenhouse ; photovoltaic cells; smart greenhouse

\section{Introduction}

\subsection{Background}

To empower farming sector, we need an effort with more modern ways in planting system. One of the ways is using a greenhouse as a farming system. A good greenhouse, especially in terms of the construction, aims on creating a weather condition which is needed and can be controlled so that the plants can grow throughout the year optimally. For this purpose, greenhouse should have a high light transmission, low heat consumption, enough and efficient ventilation, a strong structure, a low operational cost and high quality. Nevertheless, it needs a relatively high cost compared to the conventional way. Because energy is one of the most important factors, the utilization of the renewable energy is one of the factors that can lower the production cost. In this paper, the author will discuss the design of energy system for greenhouse farming. The energy used is solar cell. Solar cell is used to supply the needs of the whole system, starting from watering, sensing outdoor condition (rain and drought), opens and closes the roof, and many more.

\footnotetext{
* Corresponding author. Tel.: +62 85755136100

E-mail address: fsyifaul@gmail.com
} 


\subsection{Greenhouse and green roof}

Green roof is a method of vegetation planting on the rooftop of a house as a creative solution for limited land in the area with high population density. The method of planting vegetation on the roof is more effective than using soil and pots because it can include wider area by functioning rooftop area which is not utilized before. This method has a main purpose to restore the function of the green soil as a controller of many substances in the air.

Greenhouse is defined as a house or building which is translucent and is used to plant vegetations so that the vegetations can grow optimally and according to the expectation. Greenhouse farming has many advantages, for example: easy to control pests and diseases, automatic watering, automatic control of temperature and humidity, and can improve the quality of the production up to 5 to 15 times compared to the conventional way [1]. The main needs of the greenhouse are the sun light and the energy that is used for heating and controlling the condition of the greenhouse. The walls and the roof of the greenhouse is made from glass or polyethylene which is translucent, so that the sun heat can go in and out. In the day, about $85 \%$ of the sun light going in the greenhouse will be trapped inside and the greenhouse can be hot. The greenhouse farming has been used widely in developed countries that have four seasons. For tropical countries with two seasons such as Indonesia, the operation of the greenhouse has a slight difference than the greenhouse in countries with four seasons. In tropical areas, the energy for heating is less, yet the needs for ventilation is bigger, because tropical areas have a relatively high sun light intensity [2]. Based on two aforementioned farming methods, the authors designed a farming method which merges the two methods. this method is a smart greenhouse which is supplied by solar cell and locates it on the rooftop of a house.

\subsection{Solar cell and the installation}

Solar cell is a tool to change the solar light into electric energy. The output of the solar cell is still in the form of Direct current voltage (DC). In Indonesia, the utilization of this solar cell has many advantages, for example: (i) The energy that is used is free, (ii) the maintenance if easy and simple, (iii) there is no moving equipments, so change of spare-part and setting in lubrication is not necessary, (iv) the equipments work without producing any sound and do not have negative impact for the environment, and (v) can work automatically.

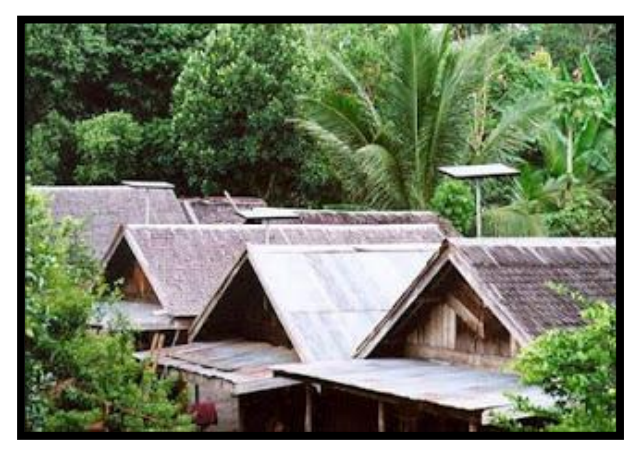

Fig. 1. The installation of solar cell. 
The placement of solar cell in tropical country such as Indonesia is tend to be flat like in Figure 1. The installation technique like this will make the morning sun light and afternoon sun light not in the exact position of the source of the light. It means that the produced electric energy will be less than expected [3].

\section{Material and method}

\subsection{Photovoltaic block diagram}

The following is a block diagram of the solar panel which is used as a power supply for the smart greenhouse project,

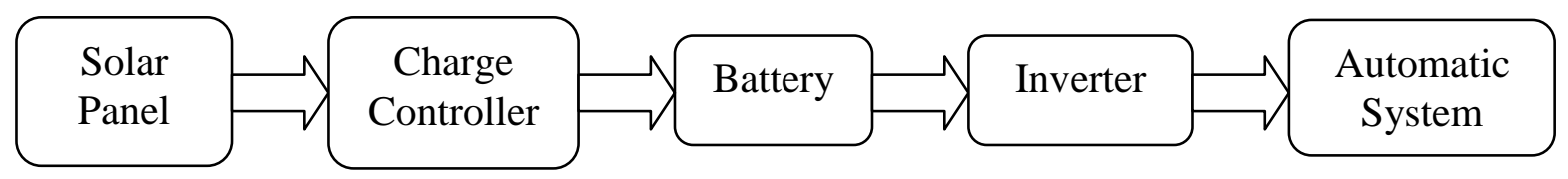

Fig. 2. Solar panel design.

\section{Description:}

- Solar panel, conversing solar energy to electric energy

- Charge controller, control the battery charging from the solar panel

- Battery, chemical equipment to store the electricity from the solar energy

- Inverter, electric equipment that converse the direct current (DC) to Alternating current (AC).

- Automatic system, as a treatment for the plants, the right light control, watering, temperature and humidity control.

\subsection{Design of solar charge contoller}

The electricity produced by the solar energy will be stored in accumulator through a charger controller. This charger controller controls the voltage and current that going into the accumulator. The charge controller is an electronic device that is used to control the direct current into the battery and taken from the battery to the charge. Charge controller can overcharging (due to the battery is already full) and the over-voltage from the solar panel, which can reduce the age of the battery. the solar panel charge controller use the Pulse Width Modulation (PWM) technology to control the battery charging function and the current exemption from the battery to the charge. Some of the detail function of the solar panel charge controller is as follows: (i) control the current for charging the battery, overcharging, over-voltage, (ii) control the current that is released/taken from the battery so that the battery does not 'full discharge' overloading, and (iii) monitoring battery temperature.

\subsection{Instalations of energy system}

The installation of the energy system using solar energy needs planning on power requirements e.g.: the amount of usage, the amount of solar panel and batteries. It is according to the power requirement that is used when charging the battery. Moreover, it needs the right voltage and power in operating the electric motor. 


\subsection{The testing of the photovoltaic cells}

The purposes of this testing are: (i) to understand the performance of the photovoltaic units towards the existed data from the manufacturer (for the comparing data), (ii) To understand the voltage and current that come from the solar panel towards the charge, and (iii) to understand the current, voltage and power, then to know the performance of the solar panel.

\section{Result and discussion}

\subsection{Solar panel installation}

Electricity is used for DC motor in smart greenhouse that will be designed as follows:

Table 1. Power requirements

\begin{tabular}{ccccc}
\hline Unit & User tool & Energy (Watt) & Duratin (hour) & $\begin{array}{c}\text { Energy Load/ Day } \\
\text { (Watt/hours) }\end{array}$ \\
\hline 1 & DC motor & 100 Watt & 10 hours & 1000 watt/hours \\
\hline & Total & & 1000 watt/hours \\
\hline
\end{tabular}

If the DC motor $100 \mathrm{~W}$ powered is turned on in total 10 hours per day (because the use is done anytime day or night, so that it is assumed the total normal use is 10 hours), the energy load for mini fridge is $100 \mathrm{Wx} 10$ hours = 1000 Watt-hours/day.

After all have been calculated, the total energy load is 1000 watt-hours/day. If throughout the year in tropical country such as Indonesia, the duration of the daylight is 7 hours/day (07.00 to 14.00). So that theoretically, the load of 1000 watt-hours/day needs two solar panels with capacity of 100 Watt; which is: $1000 /(7 * 100 / 100=1.42$ (rounded to two solar panels). Meanwhile, the need for battery is 12 volt with 1000 Ah each (the product is shown in the picture below). The calculation is as follows:

- the need for minimum battery (battery is only used $50 \%$ to fulfill the electricity need), so that we multiple the power requirement by $2: 1000 \times 2=2000$ watt hour $=2000 / 12$ volt/100 Ampere $=1.6$ batteries $100 \mathrm{Ah}$ (two batteries).

\subsection{Build design}

In building the smart greenhouse, a calculation of strong building construction is needed, which is the building has to be able to support the weight of the solar panel as well as the smart greenhouse.

$$
\text { Foundation formula }=\frac{\rho}{\sigma \tau}
$$

\section{Description:}

$\mathrm{P}$

$\sigma \mathrm{t}$

: The weight of the building which is supported by the foundation, which is:

: The soil support ability which is allowed to be used to support the load of the building on it: (i) the weight of the bricks and the practical columns, (ii) roof weight, (iii) the weight of the ceilings, (iv) Sloof beams weight, and the weight of the beams around the top, (v) the weight of the foundation itself, and (vi) the weight of the soil on the foundation. 
To calculate the construction weight from the building and the materials, we use the Indonesian Cargo Regulation, NI-18,

- The weight of the brick masonry with the plaster $1 \mathrm{kp}: 1 \mathrm{pc}: 2 \mathrm{ps}$ is $1700 \mathrm{~kg} / \mathrm{m}^{3}$. This weight is including the plaster so that the thickness of the brick masonry used is:

$15 \mathrm{~cm}$ for masonry $1 / 2$ stone

$30 \mathrm{~cm}$ for masonry 1 stone

- For sloof beams and beams around the top of the reinforced concrete construction we use the weight $=2400$ $\mathrm{kg} / \mathrm{m}^{3}$.

- For the wooden horse weigh $=60 \mathrm{~kg} / \mathrm{m}^{3}$

- Stone foundation weight $=2200 \mathrm{~kg} / \mathrm{m}^{3}$

- Dry soil-humid air $=1700 \mathrm{~kg} / \mathrm{m}^{3}$, wet soil $=2000 \mathrm{~kg} / \mathrm{m}^{3}$, this weight is also applied for sand.

If there is no soil investigation done to know the strength, the soil support ability that is allowed to be used is maximum $1 \mathrm{~kg} / \mathrm{cm}^{2}\left(=10 \mathrm{t} / \mathrm{m}^{2}\right)$. The soil support ability which is used is directly under the foundation.

$\mathrm{F}=$ the broad measure of the basis of the foundation which is planned to be used. For the top part of the foundation : $1 / 2$ stone minimum $=20 \mathrm{~cm}$ and stone minimum $=30 \mathrm{~cm}$.

For the continuous foundation only reviewed each 1 meter of the foundation length, so that $\mathrm{F}$ here is $=$ width of foundation $1 \mathrm{~m}$. Such as:

- $\quad$ Building load each $1 \mathrm{~m}$ length $(\mathrm{P})=5 \mathrm{t} / \mathrm{m}^{2}$

- $\quad$ Allowed soil support ability $(\sigma \mathrm{t})=0,8 \mathrm{~kg} / \mathrm{m} 2(=8 \mathrm{t} / \mathrm{m} 2)$.

$\mathrm{F}$ foundation $=5 / 8=0.625$, foundation width $\mathrm{b}=0.7 \mathrm{~m}$ (rounded up)

\subsection{Solar charge controller design}

To make a charge controller, the characteristics of the solar panel and accumulator needs to be noted. In this research, we use two solar panel modules, with each module has the output voltage maximum of 24 volts and maximum current of $4.2 \mathrm{~A}$. The accumulator that is used has the maximum voltage of 13.5 volt. So, we design the charger with following characteristics: (i) maximum input voltage of 24 volt, (ii) maximum output voltage of 13.5 volt and (iii) maximum current of $5 \mathrm{~A}$. As mentioned before, a good solar charger controller has the ability to detect the battery capacity. If the battery is full, it automatically stops the current charging from the solar panel.

\subsection{Photovoltaic cells testing procedure}

The parameter observed including the measurement scale periodically between 08.00 to 17.00 and once an hour seen in the measuring tool used in the testing and records it to get the value and the results that close to the actual value. The use of the measuring tool from the kind and the usefulness as used in the solar energy power supply testing system which is digital Ampere meter which is used to measure current and Analog Voltmeter which is used to measure voltage. There are several procedures that needs to be noted in solar energy power supply testing system:

- Check and observe the accuracy and precision of the measuring tools used in the testing

- to know the accurate data from the result of the testing using the measuring tools such as analog voltmeter 0$30 \mathrm{~V}$, this tool is used to know the DC voltage coming from the solar panel and to know the AC current that comes from the solar panel, so that the measuring tool which is used is digital Ampere meter (0 to 20) A.

- records the data from the measuring results from the measuring tools which is used in the testing, the measuring tools used are the analog voltmeter (0 to 30) $\mathrm{V}$ and digital Ampere meter (0 to 20) A. 
- Throughout the testing, the weather condition should be really noted because the weather condition is very influential to the performance of the solar panel.

- After the data from the testing result is collected, the next step is the making of the table and relational graphic of time and relation between current towards time.

\subsection{Virtual design}

After the authors design the solar panel installation and the building foundation, the next step is to design in the visual form. The following is the design made by the authors:

a

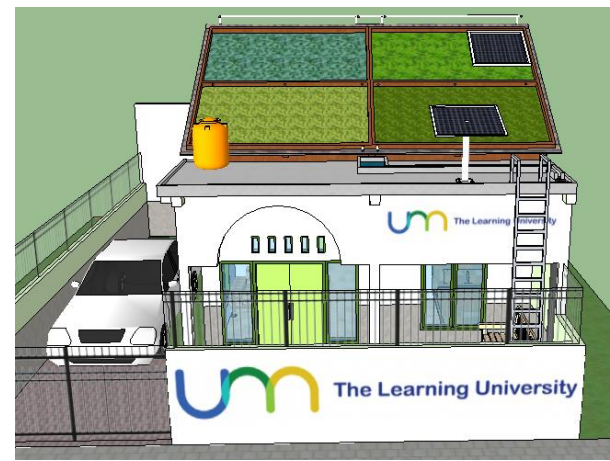

c

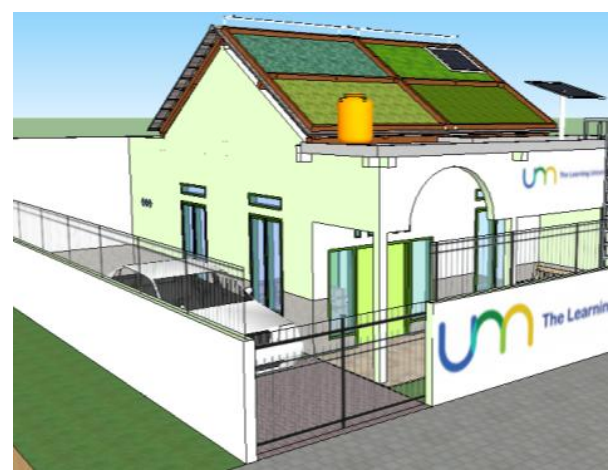

$\mathrm{b}$

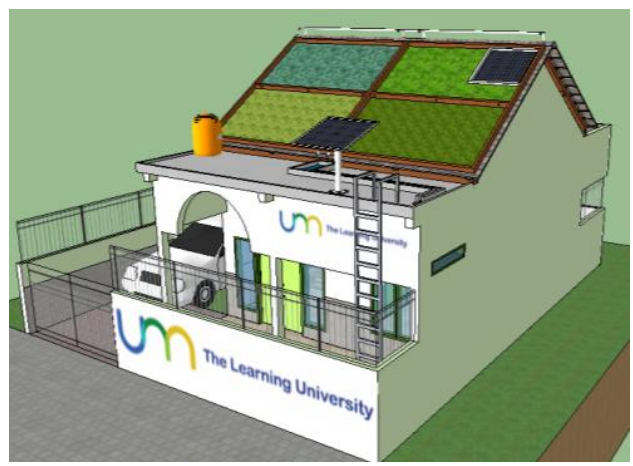

d

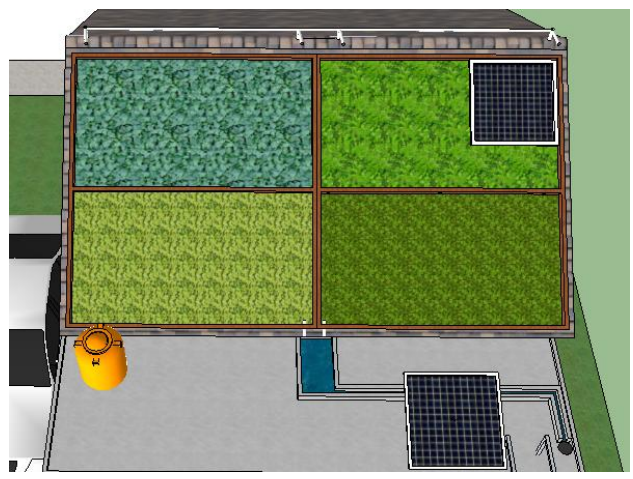

Fig. 3. (a) look forward ; (b) looks right side ; (c) looks lift side ; (d) looks up. 


\section{Conclussion}

Solar cells become one of the media that can convert the solar energy to be electric energy which is used in the smart greenhouse system. This tool becomes one of the new environmental technology and have the role in influencing the design and influencing the quality of the environment to be greener and cooler as well, and is supported by the utilization of the smart greenhouse system which helps in caring of plants such as watering, lighting, and protector of the temperature which is needed by the plants on the roof or green roof. So, if all of these are combined, it can be one of the ways to reduce the global warming and a go green step.

\section{Acknowledgements}

The authors owe gratitude to EBTKE-ConEx 2014 committee that give the opportunity to present this project.

\section{References}

[1] Robert N. Brewer, et.al., Solar Applications in Agriculture, The Franklin Institute Press, Pensilvania, 1981.

[2] Sugiyono, A. Kendali Sistem Energi Untuk Pertanian Rumah Kaca. Prosiding Seminar Nasional Penerapan Teknologi Kendali dan Instrumentasi pada Pertanian, BPPT, October 1998. p. S5-5.1 - S5-5.4

[3] Cheng, C. L., Chan, C.Y., and Chen, C.L. An empirical approach to estimating monthly radiation on south-facing tilted planes for building application, Amsterdam, Journal of Energi, Volume 31, Issue 14, p. 2940-2957 